\title{
THE OFFSHORING OF FINANCIAL SERVICES: A REASSESSMENT
}

\section{Graham Hollinshead}

Reader in International Human Resource Management,

University of Hertfordshire Business School,

Hatfield, Hertfordshire, AL10 9AB

00441707285498

\section{G.Hollinshead@herts.ac.uk}

\section{Jane Hardy}

Professor of Political Economy,

University of Hertfordshire Business School,

Hatfield, Hertfordshire, AL10 9AB

00441707285498

\section{J.A.Hardy@herts.ac.uk}

\section{University of Hertfordshire Business School Working Paper}

UHBS 2009

University of Hertfordshire Business School Working Papers are available for free download from https://uhra.herts.ac.uk/dspace/handle/2299/619

The Working Paper series is intended for rapid dissemination of research results, workin-progress, and innovative teaching methods, at the pre-publication stage. Comments are welcomed and should be addressed to the individual author(s). Papers in this series are often provisional and comments and/or citations should take this into account.

Copyright and all rights therein are retained by authors or by other copyright holders. All persons copying this information are expected to adhere to the terms and conditions invoked by each author's copyright. These works may not be reposted without the explicit permission of the copyright holder. 


\title{
THE OFFSHORING OF FINANCIAL SERVICES: A REASSESSMENT
}

\begin{abstract}
Operating in an increasingly competitive market environment, financial services companies are engaged in international re-engineering of business processes mirroring developments in manufacturing over the past four decades. Drawing upon interviews conducted with senior managers and partners from two leading international banks, a multinational 'consumables' provider and a leading finance consultancy, as well as extensive published surveys, we examine the distinctive 'anatomy' of offshoring in financial services, an industry which also manifests a high degree of geographical concentration for 'higher order' functions. We conclude that the reality of process re-engineering in the sector has frequently failed to meet business objectives, and has run the risk of creating 'backlash' from employees in both home and host environments.
\end{abstract}

\section{INTRODUCTION}

There is general agreement over the increasing importance of foreign direct investment in the services sector as a key driver of the globalisation process (Coe, 1997; Blinder, 2006; UNCTAD, 2004; Daniels, 2007). The financial services industry offers a contradictory picture of the international division of labour at the start of the new millennium. On one had the sector exemplifies 'path dependent' tendencies towards concentration of people and processes in major metropolitan centres. On the other, the 'light' and electronically transmittable nature of the financial product has permitted the re-organisation of productive activity into international 'financial factories' with scant regard for national borders.

Following the deregulation of financial services during the 1980 s and 1990s, firms have gravitated to major financial centres, this promoting geographical concentration of headquarters (Dicken, 2003). As Martin (1999;19-20) states; 
'Foreign banks and related institutions have moved into these centres precisely because of geography, that is to expand their presence or gain access to specific markets, to capitalise on the economies of specialization, agglomeration and localization (skilled labour, expertise, contact, business networks etc.) available in these centres, or to specialize their own operations and activities geographically'

Dicken (ibid) suggests that tendencies towards concentration may be attributed to the distinctive features of the finance industry, which relies upon co-operation between firms as well as competition. In a profession where contacts are vital for generating business and information about business 'relationship management' is an essential activity (Thrift, 1994: Dossani and Kenney, 2007). Similarly, Dicken (ibid) argues that 'micro networks' perform a vital function in price setting and related activity, resting upon the twin needs of sociability and proximity (Thrift, op.cit.). In the leading financial metropolises strong cultures are established which are conducive to the interpretation of complex information in a reflexive fashion and economies of scale created in factors such as linked services including accounting legal and computer based (Dicken, ibid). The relational nature of the factors that have contributed to the agglomeration of financial institutions in leading metropolitan centres have clearly accumulated over a period of time and possess a highly localised quality, scarcely being amenable to replication beyond distinct geographic boundaries.

Offsetting the trend towards concentration of 'higher order' functions, there has been a strategic realisation in recent years that economies can be gained in a highly competitive market environment by separating out 'back office' activity and relocating its performance to lower cost locations. The introduction of microcomputers and networked computer terminals has added impetus to the decentralisation of more routine functions, this leading to a 'spatial bifurcation' (Warf, 1989; 267) in many large finance firms. As Gordon et.al. (2005) point out, although there have been earlier examples of near and off-shoring of business services, particularly in the U.S., large scale interest in the relocation of a range of service activities has become most pronounced over the past five years or so in the City of London and more widely across Europe.

Although different weights are attached to the factors driving offshoring and outsourcing, agreement has coalesced that these two intertwined phenomena are driven by economic, 
organisational and institutional factors. First, increased competitiveness and the need to sustain profits has led to the de-verticalisation of firms and reengineering in order to arbitrage costs and seek new knowledge and innovation (Jacobides, 2005; Coe, 1997). The separation of work geographically and organisationally has involved longer and more complex value chains (Gupta, 2006; Gupta et al, 2006).

Second, advances in and the standardisation of technology has made skills more portable between firms, resulting in declining costs (Miozzo and Soete, 2001; Grimshaw and Miozzo, 2006), while the growth of accepted industry standards has reduced the risks of offshoring (Aspray, 2006: Graz, 2008). Taken together these have increased the distances over which the arbitrage of knowledge and labour costs can occur. Third, processes of offshoring and outsourcing will be shaped by institutional influences in sender and receiver countries (Grimshaw and Miozzo, 2006; Lakha, 1994; Balasubramanyan and Balasubramanyan, 1997). At an international level important institutional developments such as the deregulation of financial markets, GATT, TRIPS and EU enlargement have been important in differentiating the geography of space and costs (Ellis and Taylor, 2006).

Accordingly, three main sets of servicing functions are subject to relocation:

- Call centres of various kinds for marketing, routine business enquiries and more sophisticated technical support

- IT functions, including data- processing, code checking, software development and modification. Operations support, publishing and statistical analyses

- Wider business support functions of various kinds, including accounting/payroll operations, para-legal work and record maintenance.

(Gordon et al, 2005: 19)

\section{CONCEPTUAL FRAMEWORK}

While the agglomeration of finance companies' headquarters in specific global localities may be explained by notions of 'path dependence' and 'embeddedness', three interrelated strands of theory provide insight into the rationale for the international decentralisation of operating units, these reflecting earlier developments in manufacturing; 
International or spatial division of labour; Guiding the re-organisation of production across national boundaries over the past four decades in industries such as motor manufacturing and clothing has been the realisation by companies that competitive advantage would flow from retaining certain business functions 'in house', while disaggregating, or externalising, elements of the production process as appropriate overseas to realise cost efficiencies (Ghoshal, 1987). Underlying such sourcing decisions has been the strategic realisation that lower 'value added' industrial activities may most suitably located in less advanced regions, while higher grade 'knowledge orientated' skills will be the preserve of the most advanced nations. As a result of differentiated patterns of industrial development resulting from institutional and cultural diversity across national borders, different countries, and indeed regions within those countries, may offer distinctive and appropriate specialist skills.

Lean production; Closely associated with the concept of the international division of labour, and emerging as a production paradigm from the Japanese automobile industry, it was recognised in the 1970s that, although various models of vehicle were different, problems of duplication existed between many components and of the basic 'platform' on which each model was built (Dicken, ibid). Accordingly, significant rationalisation of the production process involved the reduction of platforms and components to a minimal number, each of which was shared with other models within the firm's product portfolio. (Dicken, ibid). Associated with this strategy is the concept of mass customisation which refers to the selling of highly individualised products on a mass scale, ideally reversing the production paradigm from 'production-push' to 'demand- pull'. (The Economist, 2001). The manufacturing 'imperative' of lean production has been associated with a broader and thoroughgoing debate occurring mainly in the 1980 s and early 90 s on the potential transferability of Japanese organisational principles, or Japanisation, to the U.S. and beyond (Womack et. al., 1990). Central concerns which have influenced international management thinking have been the significance of flexible production systems to meet niche consumer demands, the removal of duplication and slack in productive processes and the importance of highly committed workforces. The debate on Japanisation has been joined by the critical labour process school (for example, Turnbull, 1986, Ackroyd et.al., 1988), which has argued that the widespread inception of principles of lean production has been associated with trenchant 
assertion of managerial control, the intensification of work, and the subtle socialisation of employees into corporate value systems and cultures.

Global Production networks; There is growing recognition in the contemporary map of international business that 'jigsaws' of organisational relationships now straddle local, national, regional and global spheres. Moving away from 'linear' notions of international product manufacture or service provision, contemporary concepts of international governance recognise its complexity, involving 'horizontal, diagonal, as well as verticalforming multi- dimensional, multi- layered lattices of economic activity (Dicken, ibid,16). Following from this, international businesses in a market context are typically involved in a 'spider's web' (Dicken, ibid, 17) of collaborations with other enterprises whose resources can be utilised for competitive advantage. Typically, then, international enterprises may opt to externalise transactions to third parties, this engagement being governed by 'the market'. Alternatively, networks may be incorporated within the firm through vertical integration and organised in a hierarchical fashion (ibid). The orientation of international companies to internalise, externalise or adopt a combination is associated with the resource based view of the firm (Barney 1991) which asserts that firms gain competitive advantage through their propriety control of immobile and heterogeneous resources relating to physical capital resources (for example plant, equipment and raw materials), human capital or intangible resources (expertise, knowledge embedded in workers, relationships etc.) and organisational capital resources (for example structures and strategies, planning and controlling). Internal advantages are accrued if it is more profitable for a company to exploit its ownership advantages itself in another country, rather than to sell or license them

While the international re-organisation of production has tended to be the preserve of manufacturing companies, there is growing realisation in financial services that the above principles possess utility in a sector which is increasingly characterised by commoditisation, hyper- competitiveness, the growth of niche markets and the need for stringent cost reduction. According to a recent report by the leading financial services consultancy Capco;

'Recent research conducted jointly by a team drawn from Capco and the London Business School highlights how the world's top financial services firms are deploying new sourcing strategies and models to move up the process innovation curve. This closely resembles 
events that have already occurred in the manufacturing sector, wherein best-in-class companies like General Electric have developed sophisticated sourcing models to optimize the value chain of their operations. By componentizing their business processes, the financial services firms have begun to look at each component independently of the other components while selecting the best sourcing option...Should the trend continue tomorrow's banks would look and behave no differently to a factory' (Gupta, 2006,43)

While it is tempting to assert that new developments in financial services processes represent a repeat of earlier international business developments in the manufacturing sector, both in terms of observed practice and strategic motivations underlying change, such a conclusion should be tempered by the following observations; Firstly, the move towards business service de- construction and the establishment of modular business platforms on an international basis has occurred in a relatively small number of exemplary organisations to date. As Gupta (ibid) points out, most financial services firms are saddled with rigid, inflexible legacy technologies and processes, this problem being exacerbated by insular and risk-averse management styles. Secondly, where international business reorganisation has occurred in financial services and related business activities, it has arguably demonstrated qualitative differences from its manufacturing counterparts. It may be asserted that the service sector is potentially more 'fleet of foot' than industries engaged in production of physical products. Commitment to fixed investment is likely to be less than in manufacturing, while progress with broadband communications allows overseas work to be supervised in real time. While the growth of off-shoring in business services and related activity may be regarded as an extension of 'Business Process Outsourcing' (BPO), commonly manifesting the manufacturing based strategy of 'contracting with an external organisation to take primary responsibility for providing a business process or function' (Ghosh, 2004), it may be argued that the potential international organisational permutations available to financial concerns represent a quantum leap in complexity and sophistication.

As Gordon et.al. (ibid) reveal in their study of the City of London, the round of off- shoring activity witnessed involves both the establishment of new captive facilities owned and managed by the firm itself and outsourcing to new local vendors, many of whom are large scale suppliers to a range of international businesses who are able to benefit from 
economies of scale and scope. Irving et.al. $(2003 ; 104)$ predict that this trend will continue in a global context where;

'financial services firms learn to take full advantage of third party contract manufacturers who not only provide business processing services but make it possible for the financial services firms of tomorrow to become virtual organisations that focus predominantly on servicing their clients'

\section{THE ANATOMY OF OFF-SHORING}

The aforementioned LBS/ Capco survey (Gupta, ibid) reveals that a wide variety of strategic options are available to firms aiming to reconstruct their business operations on an international basis, these manifesting differing degrees of tightness in ownership and control. Highlighting a major contribution of the LBS/ Capco study, it is now over-simplistic to suggest that sourcing options occupy two ends of a spectrum, i.e. maintaining full control via fully operating centres or fully outsourcing end-to end- back office or Information technology; Gupta et.al. 2006).

Table 1 Outsourcing and offshoring options

\begin{tabular}{|l|l|l|l|}
\hline & On site & Near Shore & Offshore \\
\hline Complete ownership & $\begin{array}{l}\text { Status Quo } \\
\text { (neither outsourced } \\
\text { nor offshored) }\end{array}$ & $\begin{array}{l}\text { In- house, near shore } \\
\text { (captive centre in } \\
\text { nearby location) }\end{array}$ & Captive offshore \\
\hline Shared ownership & JV onshore & JV near-shore & JV offshore \\
\hline No ownership & On site vendor & $\begin{array}{l}\text { Offsite near-shore } \\
\text { vendor }\end{array}$ & Offshore vendor \\
\hline
\end{tabular}

Source: Gupta, 2006

As figure 1 denotes, complete ownership by the company may be retained on site, or through captive operations at near or offshore locations. On the other hand, ownership may be outsourced to a third party either on site, or at near or offshore locations. A range of 
factors are likely to be taken into account in deciding which ownership option to adopt, but these are likely to relate to (1) the perceived market worth of the brand or process- the risk of competitor access presenting a disincentive to devolve ownership, (2) vendor experience and technology- superior vendor knowledge of an offshore domain providing an incentive to relinquish ownership (3) Risk associated with offshore location (4) the nature of the process itself- if immature, high brand impact, or direct customer contact this is a disincentive to offshoring (Gupta et.al., ibid). The shared ownership model has remained relatively unused and experimental, but may be represented as a 'stop gap' and easily reversible (Gupta et.al., ibid)

Gordon et al's (ibid) research into off-shoring and the City of London reveals that the City based functions that are less vulnerable to relocation 'are those related to complex products and services and there is a premium on the management of risk, or involving new product development. In addition, there is strong demand for labour that can support marketing of new products that which are technically complex to put together and manage' (ibid, 6). Furthermore, many of these high added value activities depend of frequent face-to face contacts between clients, suppliers, customers and collaborators. On the other hand, this survey finds that functions that are most susceptible to restructuring and relocation are those involving business processes ' that do not require proximity to the City and are embedded in low risk 'vanilla' type products and their associated products' (ibid, 6).

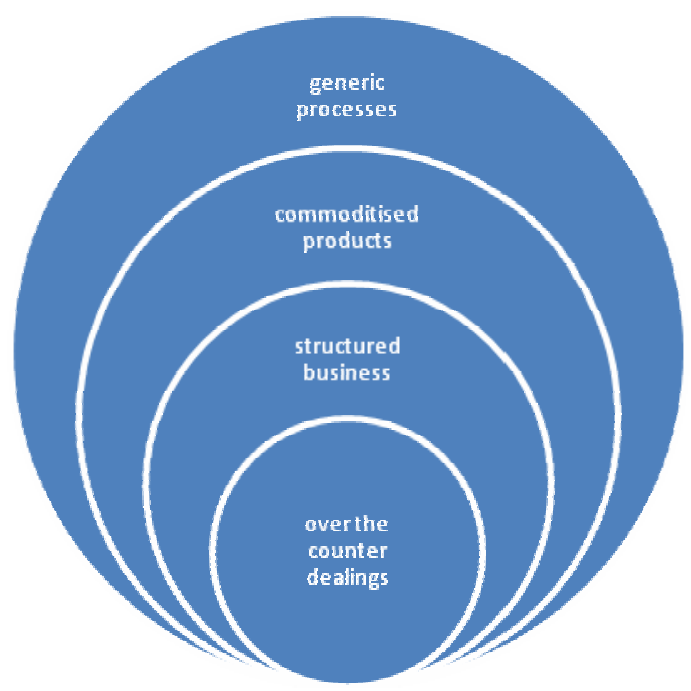

Figure 1 Onion layer model of processes amenable to relocation. Source: Gordon et al, 2005. 
Drawing upon their survey of large firms involved in financial intermediation, representing approximately half of the total investment bank employment in this area (around 63,000 staff) and upon a depiction by McCarthy et. al. (2003) on behalf of the Forrester Management Consultancy, Gordon et.al. (ibid) formulate the 'onion layer model' of processes amenable to relocation depicted in figure 2 above. The outer rings represent the supporting structures of the business, comprising functions and processes for which geographical relocation involves least risks as the value of proximity is limited and a relatively simple product offered. The innermost ring encompasses an absolute need for proximity, and represents a vital and highly personalised business resource and competitive asset.

Table 2: Risk, location and product complexity spectrum

\begin{tabular}{|l|l|}
\hline Low risk of transfer & High risk of transfer \\
Value of proximity limited & Proximity needs very high \\
Product provided simple & Product the result of complex matrix of \\
& relations
\end{tabular}

Source Gordon et al, (2005)

These authors assert that the drive to reduce costs is continually moderated by the need to control risks. Key areas of concern expressed among the contributors to their survey were confidentiality, control over contracts, assignment of intellectual property and back-up systems in offshore centres.

However, in considering the anatomy of off-shoring, it is necessary to guard against a simplistic assumption that high added value, or core, functions will be retained in house, while low added value, peripheral; functions will be subject to relocation. As Gupta (ibid) contends, there is a growing incidence of vertical business functions being subject to nearshoring and off-shoring. This author (ibid) provides an example of an investment bank which planned to offshore as much of a derivative related process to India in order to reduce costs. As a first move, the bank decided to offshore confirmation processes. The offshore centre in India took over responsibility for initiating (phone calls, e-mails etc.) to the parties, while the 
more experienced resources based in London processed exceptions. Using this model, the investment bank was able to minimise investment in knowledge transfer and training of staff in India, while saving around $40 \%$ of operating costs (ibid;46).

Our case analysis of a US based financial corporation, (which we refer to as 'the company' for reasons of anonymity), reveals that the cost-risk strategic tension also impacts upon the outsourcing/ off-shoring process, this company adopting an incremental, phased approach to relocation of business function, a practice which is undoubtedly common among comparator companies.

In Phase 1, in order to reap immediate benefits from the outsourced environment, product support maintenance was outsourced to India. This provided the company with the opportunity to gain experience of off-shoring and to learn from its Indian vendors which had considerable experience in this area.

In Phase 2 the company's target was to lay down multiple off-shoring/ outsourcing layers. Accordingly outsourcing occurred in Europe, Mexico, India, the Philippines and Canada. In Canada a dedicated centre was established due to relatively low labour costs.

In Phase 3, the aim was to consolidate the relocation process and to resolve deficiencies emerging in phases 1 and 2. In 2003 the company commenced operations in China. A new centre was established to access low cost technological resources. Additionally the company's own equity was transposed to China by entering into joint ventures with banks and by the company establishing its own vendor operations.

Throughout, the company was aware of the risks associated with off-shoring, and particularly the political risks evident in India and Pakistan. In order to protect the company, the data management process was deigned to ensure that all documentation was kept in a library that could be accessed from anywhere in the world.

The company recognised also that as it proceeded from phases one to three, risks associated with factors such as language, culture, the legal system and intellectual property rights protection increased, while costs decreased. 
The preference of companies to adopt a cautious approach to off-shoring was also borne out in the study by Gordon et al (ibid). These authors found that senior managers in the finance sector preferred to pilot relocation moves and expand incrementally before making a full commitment. For example, an asset management company had decided to move a substantial amount of work to Bangalore, but were starting with a small pilot operation, with 100-200 staff, to 'test the water'. In another example, an investment bank had moved 15 jobs to an existing credit card centre in Glasgow to see whether it was feasible to break with their previous commitment to run operations entirely in the City of London. This was followed, a few years later, with a move of 320 jobs to Glasgow on grounds of cost rather than capacity.

\section{FACTORS GUIDING THE SELECTION OF HOST ENVIRONMENT}

It follows from the above analysis that the selection of the host environment by firms seeking to offshore/ outsource will be guided by three major factors which may be regarded as being in tension. (1) cost, and particularly labour costs (2) the reservoir of skill availability in the recipient country (3) degree of risk inherent in the host environment. A concomitant of factor (1) is the package of tax and other financial inducements frequently offered by host governments to inward investors, particularly when they are locating in designated free trade areas. In relation to factor (2), we should note that skill requirements will vary according to both the type of business function being off-shored (demanding specialist areas of expertise which may be available in various regions), as well as the overall status of technological and other relevant knowledge in the host environment as a product of its educational and training system. Of course, skill is not a static phenomenon, and our respondents referred to a 'learning curve' which was frequently experiences by host employees. As recipient regions became more far- flung, off-shoring companies are increasingly aware of the degree of political and business risk that accompanies investment decisions, for example in India. However, it is important to note that such risks were mediated by companies by rendering vendors or third parties liable for unpredictable business aspects emanating from the host country, this engaging in a process of 'externalisation' (Bakan, 2004). 
While the bulk of off-shoring activity in financial services and related activities continues to favour India as the host destination, our fieldwork has revealed a growing view among experts that major Indian cities are reaching a 'saturation point' as focal points for offshored service operations. In consequence companies are surveying other global regions, including Eastern and Central Europe and Russia, as well as China as possible venues for relocation. Contingent factors impacting upon a possible change in the geographic trajectories of sourcing in the future include (1) time zones (temporal closeness to London and New York Stock Exchange operating periods) (2) political influence (for example, the European Union supporting intra European investments), (3) staff loyalty, labour arbitrage and skilled resources (which is available in many East European countries) (4) Language proficiency (particularly in English) and cultural proximity (4) Deterrents against intellectual leakage, which may be related to institutional stability as well as staff loyalty.

\section{THE DYSFUNCTIONAL EFFECTS OF OFF-SHORING: BUSINESS AND EMPLOYMENT IMPLICATIONS}

In early 2005 two major North American based consultancies predicted that fifty percent of off-shoring contracts signed by U.S. companies between 2001 and 2004 would fail to meet expectations. In such circumstances, Aron and Singh (2005) note that 'in-shoring and insourcing' have enjoyed a growth in popularity in business circles. Critical explanations for the failure of off-shoring relate essentially to mis- management of the process by nonexemplary organisations. Thus, despite the 'best practice' recommendations of consultancies and agencies such as Capco, companies in practice fail to systematically differentiate and measure the added value of discrete operational elements to establish a value hierarchy, and therefore relocate functions in a relatively arbitrary fashion (Aron and Singh, ibid). Similarly, the various possible organisational permutations associated with offshoring (see figure 1) are not being given full consideration, companies tending to conceive a simple dichotomy between in-shoring and off-shoring (ibid). Further difficulties relate to the role of the vendors in the host environment and to the quality of off-shored processes. Following the completion of contractual formalities, it is the case that vendors display differing degrees of reliability concerning, for example, the recruitment of adequately trained staff. Vendors, however, may find themselves in a near monopoly provision in the provision of lower order yet critical business functions and therefore can demand price 
hikes in contract re-negotiation (ibid). Such problems are perpetuated due to inadequate establishment of 'metrics' to measure the quality of off-shored processes (ibid).

In the field of employment, serious concerns have been expressed about the effects of offshoring on work in both home and host environments. The premise fuelling controversy of concerning the international relocation of jobs is well captured by Robert- Nicoud $(2008,517)$ as follows;

' Offshoring, or overseas sourcing of routine tasks, generates efficiency gains that benefit consumers and workers with skills similar to those whose jobs are threatened by offshoring. Essentially, the interaction between offshoring, footloose capital and agglomeration economies locks the comparative advantage of advanced nations in complex or strategic functions while labour services in 'routine' tasks, the coordination of which is easily codified, are provided by developing nations through the fibre optic cable'.

Thus, from a home country perspective, workers engaged in routine activities are threatened by shifts in their functions to lower cost global regions. The potential for 'backlash' in the West has been flagged by Taylor and Bain (2003) who note two prominent trade union campaigns in the UK, firstly to prevent the transfer of call centre jobs from Reading to Mumbai and, secondly, to oppose British Telecom's decision to establish call centres in Bangalore and Delhi. The expression of alarm and despondency by those most adversely affected by the restructuring of international employment systems has occurred across many western countries, including the United States. Furthermore, as argued above, domestic employees may be subject to 'near- shoring' experimentation by finance companies prior to more fully fledged strategic moves to off-shore. Such employees are clearly vulnerable, and confront an unfortunate 'double bind' in so far as successful performance within the near shored unit may provide the rationale for its discontinuation and relocation.

From the perspective of the recipient or host environment, while indigenous stakeholders may be disposed to accept the principle and economic benefits of inward investment, sanguine reflection on the strategic realities of relocation and off-shoring may promote greater equivocation on their part. Our analysis above would confirm the notion that higher value, knowledge based, financial functions are invariably retained in house, while routine 
activity is subject to relocation overseas. While closer scrutiny of the anatomy of off-shoring reveals that, in exceptional cases, 'vertical' functions' may be subject to international devolution, such moves are invariably accompanied by close control from the centre as well as the possibility of technological 'shadowing' and backup of critical computational functions. Where 'voice', or call centre operations, are off-shored, as these demand vital interface with customers, the contribution of overseas employees is frequently subject to rigid codification and, following Taylor and Bain (ibid), 'neo- colonial' forms of socialisation and training may be asserted,

\section{CONCLUSION}

In concluding this paper, and drawing upon theoretical trajectories expounded at the outset, the following critical observations may be made concerning the re-engineering of service provision organisation across national boundaries.

Firstly, drawing upon the 'resource- based view of the firm, it is clear that those resources contributing most directly to comparative advantage are being retained in house, which is insulated by the reserves of tacit knowledge required to sustain high value operations. By implication, overseas employment dependent upon more mobile attributes relating to 'vanilla' type activity is inevitably less secure in its nature. Where higher value activities have been relocated to overseas locations they have tended to be subject to rigid or 'captive' control by the centre, with vertical integration and rights of 'ownership' being asserted .

Secondly, while international companies have capitalised on low-cost conditions in host environments, as well as exploiting the indigenous, tacit knowledge of indigenous vendors and employees, they have tended to externalise associated risks to third parties operating on their behalf in the region in question. Thus notions of ownership and internalisation have been applied in a highly pliable fashion, being applied tightly when contributing to cost effectiveness and loosely in the accumulation of political and economic risk.

Thirdly, the 'phased' and cautious approach to international sourcing outlined above, frequently involving near shore 'piloting' as an interim measure, may be regarded as promoting insecurity among affected employees. 


\section{REFERENCES}

ACKROYD, S., BURRELL, G., HUGHES, M., WHITAKER, A. (1988) The Japanisation of British Industry? Industrial Relations Journal, 19, 11-23

ASPRAY, W., MAYADAS, F., and VARDI. Y. (2006) Globalization and Offshoring of Software: S Report of the ACM Job Migration Task Force, US: Association for Computing Machinery.

ARON, R. and SINGH, J.V. (2005) Getting Offshoring Right, Harvard Business Review, December

BAKAN, J. (2004) The Corporation; The Pathological Pursuit of Profit and Power, London, Constable

BALASUBRAMANYAN, V.N. and, BALASUBRAMANYAN A. (1997) 'International trade in services: the case of India's software', The World Economy, 20, 6: 829-844.

BARNEY, J. (1991) Firm resources and sustained competitive advantage' Journal of Management, 17(1) 99-120

BLINDER, A. S. (2006) 'Offshoring: the next industrial revolution', Foreign Affairs, March/April.

COE, N. (1997) 'Internationalisation, diversification and spatial restructuring in transnational computing firms: case studies from the U.K. Market', Geoforum, Vol. 28, No. 3-4: 253-270.

DANIELS, P.W. (2007) 'A global service economy' in J.R. BRYSON and P.W. DANIELS, The Handbook of Service Industries, Cheltenham: Edward Elgar: 103-125.

DICKEN, P. (2003) Global Shift; Reshaping the Global Economic Map in the $21^{\text {st }}$ Century, London, Sage

THE ECONOMIST, $14^{\text {th }}$ July, 2001

ELLIS, V. and TAYLOR, P. (2006) 'You don't know what you've got till it's gone': recontextualising the origins, development and impact of the call centre', New Technology, Work and Employment, Vol. 21, No. 2: 107-122 
GHOSH, D. (2004) Business Process Outsourcing-A Mechanism to Galvanize Shareholder Value, Journal of Financial Transformation, The Capco Institute

GHOSHAL, S. (1987) Global Strategy: An Organizing Framework' Strategic Management Journal, vol 8, 425-440

GORDON, I, HASLAM, C., MCCANN.P.,SCOTT-QUINN, B. (2005) Off-shoring and the City of London, ISMA Centre, The University of Reading

GRAZ, J.C (2008) 'Connecting India: the intermediation of standards in the global political economy of service offshoring', paper presented at EAEPE conference, Rome, 6-8 November.

GRIMSHAW, D. and MIOZZO, M. (2006) 'Institutional effects on the IT sourcing market: analysing clients, suppliers and staff transfer in Germany and the UK', Organization Studies, 27, 9: 1229-1259.

GUPTA, S. (2006) Financial Services Factory, Journal of Financial Transformation, The Capco Institute

GUPTA, S., PURANAM, P. SRIKAMTH, K. (2006) Services sourcing in the banking and financial services industries; Exploding myths and describing emerging best practice, The Capital Markets Company N.V. and London Business School

HARZING, A.W. (2004) The International Division of Labour, in A.W. Harzing and J. Van Ruysseveldt (eds.) International Human Resource Management, London, Sage

IRVING, B. SHOJAL, S. and GUPTA, S. (2003) Discovering the Endgame in the Off-shore Debate, Journal of Financial Transformation, The Capco Institute

JACOBIDES, M. G. (2005) 'Industry change through vertical disintegration: how and why markets emerged in mortgage banking', Academy of Management Journal, 48, 3: 465-498.

LAKHA, S. (1994) 'The New International Division of Labour and the Indian Software Industry', Modern Asian Studies, 28, 2: 381-394.

MARTIN, R. (1999) The new economic geography of money, in R.Martin (ed.) Money and the Space Economy, Chichester, Wile 
McCARTHY, J.C., ROSS, C.F., SHWABER, C. (2003) 'Users' Off-shore Evolution and its Governance Impact, Forrester Brief, Forrester Research Inc.

MIOZZO, M. and SOETE, L. (2001) 'Internationalization of services: a technological perspective, Technological Forecasting and Social Change, 67: 159-185.

ROBERT- NICOUD, F. (2008) Offshoring of routine tasks and (de) industrialisation: Threat or opportunity - And for whom?, Journal of Urban Economics 63, 517-535

TAYLOR, P. and BAIN,P. (2003) Call Centres in Scotland and Outsourced Competition form India, Scotecon, University of Stirling

THRIFT, N.J. (1994) On the social and cultural determinants of international financial centres: the case of the City of London, in S. Corbridge, R.Martin, and .J. Thrift (eds.),Money, Power and Space. Oxford, Blackwell

TURNBULL, P.J. (1986) The Japanisation of production and industrial relations at Lucas Electrical, Industrial Relations Journal, 17, 193-206

UNCTAD (2004) World Investment Report: The Shift Towards Services, New York and Geneva: United Nations.

WARF, B. (1989) Telecommunications and the globalization of financial services, Professional Geographer, 41

WOMACK, J.P., JONES, D.T., ROOS, D. (1990) The Machine that Changed the World, New York, Macmillan. 